\title{
RANCANG BANGUN APLIKASI MOBILE PENGENALAN GEDUNG DENGAN TEKNOLOGI AUGMENTED REALITY BERBASIS MARKER
}

\author{
Togu Novriansyah Turnip*1, Lidya Pebrina Manurung ${ }^{2}$, Marthin Halomoan Tampubolon ${ }^{3}$, Ronaldo \\ Sitanggang ${ }^{4}$ \\ 1,2,3,4 Teknologi Informasi, Institut Teknologi Del \\ Email: 1'togu@del.ac.id, ${ }^{2}$ lidyafeehily@gmail.com, ${ }^{3}$ marthintampubolons@gmail.com, \\ 4sitanggang761@gmail.com \\ *Penulis Korespondensi
}

(Naskah masuk: 13 Desember 2020, diterima untuk diterbitkan: 09 Juni 2021)

\begin{abstract}
Abstrak
Universitas atau kampus merupakan institusi pendidikan tinggi dan penelitian yang memberikan gelar akademik dalam berbagai bidang. Kampus tentunya memiliki beberapa gedung yang dapat digunakan sebagai ruangan kelas, laboratorium, ruang dosen, dll. Pada waktu tertentu sebuah kampus tidak jarang dikunjungi oleh tamu, yang berkeliling kampus dan mengunjungi gedung-gedung di lingkungan kampus. Tidak hanya tamu, Kampus juga kedatangan mahasiswa baru setiap tahun ajaran baru. Setiap kegiatan tur kampus yang dilakukan tamu maupun mahasiswa baru, harus selalu dituntun oleh dosen maupun mahasiswa. Berdasarkan kasus tersebut, penelitian ini bertujuan untuk mengimplementasikan Teknologi Augmented reality (AR) dengan menggunakan metode MarkerBased. Aplikasi ini menjadi aplikasi yang dapat digunakan sebagai pengenalan gedung kampus. Setiap gedung akan mempunyai marker atau penanda unik khusus yang berbeda pada setiap gedung. Konsep dari pengimplementasian aplikasi ini adalah, dengan mengarahkan kamera yang dibuka melalui aplikasi ini dan mengarahkan kamera tersebut ke marker yang ditemui di gedung yang sedang dikunjungi. Kamera akan mengidentifikasi marker, jika marker dikenali maka objek 3D dari gedung tersebut akan muncul tepat diatas marker untuk memberikan pengguna bagaimana bentuk keseluruhan gedung. Tidak hanya objek 3D, aplikasi juga menyediakan informasi mengenai gedung tersebut dan juga gambar dari posisi user beserta dua gedung terdekat yang dapat dikunjungi pengguna setelahnya. Dengan menggunakan aplikasi ini, pengunjung tidak memerlukan seseorang untuk menuntunnya berkeliling di sekitaran kampus. Aplikasi ini sudah diuji dengan usability testing dan kepuasan pengguna mencapai 83,4 \% yang berarti bahwa aplikasi dapat digunakan dan berfungsi bagi pengguna.
\end{abstract}

Kata kunci: augmented reality (AR), marker-based, objek 3D, aplikasi, informasi

\section{DESIGN AND BUILD MOBILE APPLICATION OF BUILDING INTRODUCTION USING AUGMENTED REALITY TECHNOLOGY WITH MARKER-BASED METHOD}

\begin{abstract}
The university or campus is a higher education and research institution that provides academic degrees in various fields. The university certainly has several buildings that can be used as classrooms, laboratories, lecturers' rooms, etc. At a certain time, a university is not infrequently visited by guests, who tour the campus and visit buildings in the university environment. Not only guests, but the University also has new students every new school year. Every campus tour activity carried out by guests or new students, must always be guided by both lecturers and students. Based on these cases, this study aims to implement Augmented reality (AR) Technology using the Marker-Based method. This application is a building recognition application that can be used at a University. Each building will have a unique marker on each building. The concept of implementing this application is, by directing the camera opened through this application and directing the camera to the marker found in the building being visited. The camera will identify the marker, if the marker is recognized then the $3 D$ object of the building will appear directly above the marker to give the user what the overall shape of the building looks like. Not only $3 D$ objects, but the application also provides information about the building and also a picture of the user's position along with the two closest buildings that the user can visit afterward. By using this application, visitors do not need someone to guide them around the campus. This application has been tested with usability testing and user satisfaction reaches $83,4 \%$ which means that the application can be used and functioning for the user.
\end{abstract}

Keywords: augmented reality (AR), marker-based, 3D object, application, information 


\section{PENDAHULUAN}

Universitas atau kampus adalah lembaga pendidikan tinggi yang meluluskan mahasiswamahasiswa dengan berbagai bidang ilmu. Kampus memiliki beberapa gedung yang digunakan oleh civitas kampus dalam menjalankan tugas dan kehidupan kampus setiap harinya. Setiap tahunnya, seluruh kampus di Indonesia, contohnya Institut Teknologi Del (IT Del) membuka tahun ajaran baru bagi ratusan mahasiswa baru. Bukan hanya mahasiswa baru, tetapi biasanya kampus juga sering menerima tamu dari luar, baik itu dosen tamu, keluarga mahasiswa, ataupun pengunjung biasa. Untuk memperkenalkan lingkungan dan gedung yang ada di sekitaran kampus, diperlukan satu program khusus yang dipandu oleh senior kepada calon mahasiswa - mahasiswi baru. Khusus untuk tamu, diperlukan salah seorang dosen atau staf atau mahasiswa untuk membawa tamu berkeliling serta memperkenalkan gedung - gedung yang ada. Tetapi cara ini menimbulkan masalah, karena membutuhkan banyak waktu oleh berbagai pihak untuk mengenal lingkungan kampus. Setelah dilakukannya pengenalan lingkungan, mahasiswa - mahasiswi baru maupun tamu belum tentu mengingatnya dan harus kembali bertanya tentang gedung atau tempat yang sudah dikunjungi. Khususnya setelah adanya pandemik COVID 19, mahasiswa - mahasiswi harus melakukan PJJ (Perkuliahan Jarak Jauh) dari rumah masing - masing karena belum dapat datang langsung ke kampus.

Teknologi Augmented reality merupakan teknologi yang menggabungkan benda maya dua dimensi di sebuah lingkungan nyata tiga dimensi lalu memproyeksikannya dalam waktu nyata (Wiradarma, 2017). Menghubungkan dunia fisik dan digital sudah lama menjadi tujuan berdirinya dari Augmented reality. Pengenalan gambar sering digunakan untuk memperoleh informasi tautan dari eksplisit atau penanda implisit dalam sebuah adegan dan untuk memicu proses (Jonathan, 2007). Ada 2 jenis metode dalam Augmented reality yaitu, Marker Based Tracking dan Markerless Augmented reality (Lyu, 2012). Marker-Based Augmented reality adalah salah satu metode dari teknologi Augmented reality yang menggunakan marker sebagai penanda yang dibaca oleh kamera yang kemudian teridentifikasi. Setelah marker diidentifikasi oleh kamera akan keluar informasi berupa gambar atau tulisan yang dimiliki oleh marker tersebut. Aplikasi akan menampilkan informasi secara real time, yaitu menggabungkan tampilan pada dunia nyata dan animasi yang didapatkan dari marker yang teridentifikasi. Augmented reality bertujuan menyederhanakan kehidupan pengguna dengan membawa informasi virtual tidak hanya ke lingkungan terdekatnya, tetapi juga ke tampilan tidak langsung dari lingkungan dunia nyata, seperti streaming langsung video. AR meningkatkan persepsi baik pengguna dan interaksi dengan dunia nyata.

Dengan berkembangnya teknologi Augmented reality untuk aplikasi pengenalan gedung seperti aplikasi campus guide, penggunaan teknologi ini dapat mengatasi masalah yang terjadi, sekaligus memberikan kenyamanan dan mempersingkat waktu dalam pencarian informasi mengenai tempat yang sedang dikunjungi. Metode marker-based dipilih karena setiap gedung memiliki sebuah penanda khusus yang tidak dimiliki oleh gedung lain. Melalui penanda atau marker tersebut maka gedung dapat dikenali dengan mudah oleh aplikasi. Pada pembuatan aplikasi android dengan menggunakan Marker-Based Augmented reality untuk program pengenalan lingkungan kampus, diharapkan setiap mahasiswa - mahasiswi baru dan tamu dapat mengetahui informasi tentang lingkungan atau gedung di kampus dengan cepat dan tepat tanpa harus dipandu oleh senior ataupun dosen/staf sebagai guide. Selain terdapat pada masing - masing gedung, saat ini marker atau penanda kampus juga dapat dilihat di website yang sudah disediakan kampus. Dengan ini, mahasiswa yang sedang mengikuti kegiatan PJJ dapat mengenali kampus tanpa mendatangi kampus. Aplikasi yang serupa juga telah diimplementasikan di Universitas Siliwangi yang berguna sebagai wadah pengenalan kampus (Prasetya, 2018).

\section{METODE PENELITIAN}

Metode pengembangan aplikasi mobile yang digunakan penulis menggunakan tahap - tahap SDLC (Software Development Life Cycle) yang dapat dilihat pada Gambar 1.

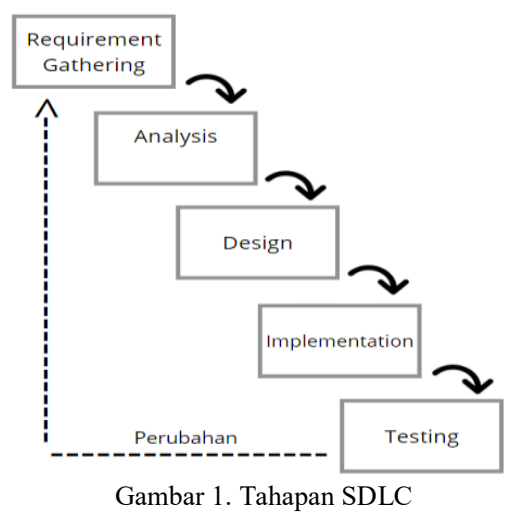

\subsection{Pengumpulan Kebutuhan}

Langkah ini adalah metode yang digunakan untuk pengumpulan data dalam mendapatkan kebutuhan aplikasi yang akan diimplementasikan atau dibangun. Tahapan ini juga akan digunakan dalam pengumpulan informasi yang akan disediakan oleh aplikasi ini. 


\subsection{Analisis}

Pada tahap ini dilakukan analisis dan pengembangan terhadap kebutuhan pengguna sistem perangkat lunak (user) dan kebutuhan pengguna. Pada tahap ini juga, penulis membuat dokumen kebutuhan fungsional.

\subsection{Desain}

Pada tahap ini dilakukan perancangan aplikasi dari analisis yang telah dilakukan untuk pembuatan rancangan yaitu sebuah aplikasi pengenal Gedung ini.

\subsection{Implementasi}

Pada tahap ini semua rancangan yang sudah dibuat akan diimplementasikan ke dalam bentuk kode-kode program sesuai dengan kebutuhan yang sudah dideskripsikan sebelumnya.

\subsection{Pengujian}

Pada tahap ini hasil implementasi akan diuji. Pengujian menggunakan pendekatan black-box testing. Hal ini dilakukan untuk memastikan dan menjamin bahwa aplikasi telah berjalan sesuai dengan implementasi yang dilakukan.

\section{TINJAUAN PUSTAKA}

Pada tinjauan pustaka, dijelaskan mengenai rangkuman dari teori-teori yang mendukung penelitian.

\subsection{Android}

Android merupakan sistem operasi yang digunakan mobile yang merupakan pengembangan dari sistem operasi Linux. Android dulunya dikembangkan oleh startup dengan nama yang sama, Android, Inc pada tahun 2005, sebagai bagian dari strategi untuk memasuki ruang mobile, Google membeli Android dan mengambil alih pekerjaan pembangunan (serta tim pengembang). (DiMarzio, 2017).

\subsection{Teknologi Augmented Reality}

Augmented reality membuat pengguna mungkin untuk melihat dunia atau lingkungan asli dengan benda - benda digital virtual tidak nyata yang ditumpangkan dan digabungkan dengan dunia nyata melalui layar smartphone, jadi teknologi ini sama sekali tidak menghilangkan tampilan asli dunia nyata pada layar, tetapi hanya menambahkan digital content (Azuma, 1997).

\subsection{Marker-Based Tracking Augmented reality}

Marker di Augmented reality adalah ilustrasi yang biasanya merupakan ilustrasi hitam dan putih persegi dengan batas hitam tebal dan latar belakang putih (Qualcomm, 2012). Proses yang dimiliki oleh metode ini adalah melakukan pelacakan berdasarkan marker. Sebelum pelacakan, tahap input image dilakukan terlebih dahulu. Dimana prosesor mengolah bingkai marker secara langsung. Kemudian akan dilakukan gambar thresholding dimana gambar dipisahkan antara latar belakang dan objek melalui tingkat kecerahan image untuk menghasilkan gambar hitam putih. Proses pelacakan atau pendeteksian marker terdiri dari empat proses, yaitu ekstraksi kontur, deteksi sudut, normalisasi pola dan pencocokan template. Proses ekstraksi kontur dan deteksi sudut, memanfaatkan gambar hitam putih untuk mendapatkan koordinat dari empat sisi dan empat titik sudut marker. Selanjutnya langkah normalisasi pola berfungsi untuk menormalisasikan bentuk dari marker agar proses pencocokan template dapat berhasil dilakukan. (Christoper, 2012)

\subsection{Gambar 3D}

Gambar tiga dimensi atau sering disebut Gambar 3D adalah sebuah objek atau ruang yang memiliki panjang, lebar, dan tinggi yang memiliki bentuk (Sudjana, 2011). Setelah proses pelacakan berhasil, tahap selanjutnya adalah tahap perkiraan posisi. Langkah ini yang bertanggungjawab untuk proses pembuatan objek maya di atas marker. Objek 3D sebagai objek virtual dari gedung akan diletakkan tepat di atas marker gedung yang merupakan objek real. Objek 3D dibangun menggunakan software Blender. Blender adalah paket pembuatan 3D sumber bebas dan terbuka (Dovramadjiev, 2018).

\subsection{Unity}

Unity merupakan aplikasi pengembangan game yang berupa lintas platform. Unity $3 \mathrm{D}$ adalah sebuah tool yang terintegrasi untuk membuat game, arsitektur bangunan dan simulasi. Menggunakan Unity 3D dapat membantu untuk menghasilkan medan, mengimpor model bangunan utama yang sudah dibangun ke medan, dan menempatkannya sesuai dengan posisi dan sudut yang sebenarnya (An Jiahui, 2019). Unity mempunyai SDK yang bernama Vuforia. Vuforia merupakan SDK yang disediakan oleh Qualcomm untuk membantu developer membuat aplikasi-aplikasi Augmented reality (AR) di mobile phones (iOS, Android). Vuforia menggunakan teknologi Computer Vision untuk mengenali dan melacak gambar planar (Target Image) dan objek 3D sederhana seperti, seperti kotak secara realtime (Putra, 2015).

\section{HASIL DAN PEMBAHASAN}

Pada bagian ini akan membahas tentang pengumpulan kebutuhan, analisis, desain, implementasi, dan pengujian dari aplikasi pengenalan 
gedung yang dibangun sesuai dengan tahap-tahap SDLC.

\subsection{Pengumpulan Kebutuhan}

Dari observasi dan pengumpulan kebutuhan yang dilakukan, maka didapatkan kebutuhan yang diperlukan dalam pembangunan aplikasi pengenalan gedung.

\subsubsection{Dataset Gedung}

Aplikasi yang akan dibangun adalah aplikasi pengenalan gedung yang menggunakan teknologi augmented reality berbasis marker. Aplikasi ini akan menampilkan objek 3D dari gedung sebagai benda virtual yang akan ditampilkan di atas marker. Pada Gambar 2 dan Gambar 3 adalah contoh gambar gedung yang akan menjadi model dari pembangunan objek 3D yang akan ditampilkan pada aplikasi.

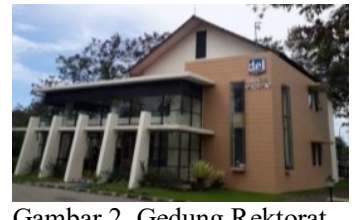

Gambar 2. Gedung Rektorat

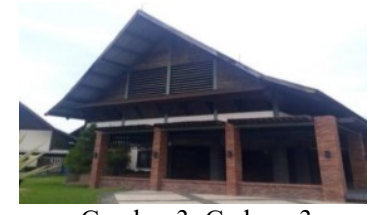

Gambar 3. Gedung 3

\subsubsection{Dataset Informasi}

Aplikasi yang dibangun akan menampilkan informasi mengenai gedung kampus, contohnya Institut Teknologi Del. Berikut contoh informasi yang akan ditampilkan pada aplikasi:

\section{a. Gedung Rektorat}

Gedung rektorat adalah gedung yang pertama sekali ditemukan saat memasuki gerbang IT Del. Lantai pertama terdiri dari 6 ruangan yaitu ruang human resources department (HRD), ruang rapat, ruang wakil rektor 1 dan 2, ruang inventori, dan ruang keuangan. Lantai kedua terdiri dari 4 ruangan yaitu ruang rektor IT Del, ruang rapat rektorat, ruang wakil rektor 3, dan ruang tim promosi.

\section{b. Gedung (GD) 3}

Gedung (GD) 3 merupakan gedung yang berada tepat di samping gedung entrance hall. Gedung ini memiliki dua lantai yang terdiri dari beberapa ruangan termasuk ruang direktur pendidikan, ruang administrasi, ruang toba digital valley, common room, network operation center dan meeting room. Ada sebuah meja dan kursi tepat pada lantai satu gedung yang biasa digunakan sebagai tempat pertemuan dosen, keasramaan, bagian kemahasiswaan, dan orangtua mahasiswa atau mahasiswi.

\subsection{Analisis}

Dari observasi dan wawancara yang dilakukan, ditemukan bahwa aplikasi akan terdapat dua aktor yaitu adalah pengguna (berbasis mobile) dan administrator (berbasis web).

Table 1. Aktor Aplikasi

\begin{tabular}{cl}
\hline \multicolumn{1}{c}{ Aktor } & \multicolumn{1}{c}{ Keterengan } \\
\hline Pengguna & $\begin{array}{l}\text { Pengguna terdiri dari semua orang yang } \\
\text { menggunakan aplikasi, khususnya tamu dan }\end{array}$ \\
& mahasiswa baru. Pengguna menggunakan \\
& aplikasi untuk mengetahui informasi \\
& mengenai gedung, melihat posisi user dan \\
& melihat objek 3D gedung, agar tidak perlu \\
& mengelilingi gedung. \\
Administrator & $\begin{array}{l}\text { Administrator atau admin adalah orang yang } \\
\text { berperan untuk mengelola data informasi } \\
\text { yang dimiliki oleh gedung yang ditampilkan } \\
\text { dalam aplikasi. }\end{array}$ \\
&
\end{tabular}

\subsubsection{Use Case Aplikasi}

Menurut dari proses observasi dan wawancara, dapat diketahui bahwa sistem akan mempunyai kebutuhan fungsional. Kebutuhan fungsional pada aplikasi dapat dilihat dari sebuah rancangan use case. Use case dari pembuatan aplikasi dapat dilihat pada Gambar 4. Untuk pengguna, aplikasi akan memberikan informasi mengenai gedung, posisi user saat mengunjungi gedung, dan objek 3D dari gedung yang akan menampilkan penggunaan teknologi augmented reality. Objek 3D sebagai objek virtual akan berada tepat di atas marker yang mana adalah sebagai objek real-time. Aplikasi ini juga akan terintegrasi dengan sistem admin yang dioperasikan oleh admin untuk mengelola informasi yang akan ditampilkan pada aplikasi.

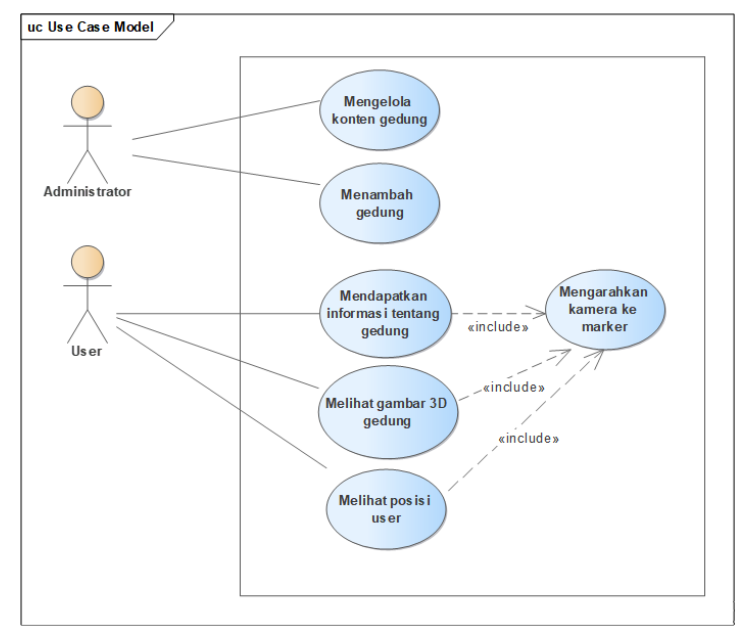

Gambar 4. Use Case Pembuatan Aplikasi

\subsubsection{Arsitektur Aplikasi}

Arsitektur aplikasi terdiri dari aplikasi berbasis mobile dan web. Arsitektur yang menjelaskan 
interaksi antara sistem bagian pengguna dan sistem bagian administrator dapat dilihat pada Gambar 5 .

Untuk pengguna, aplikasi yang digunakan adalah aplikasi berbasis android dengan mengimplementasi teknologi marker-based augmented reality. Aplikasi menyimpan semua marker di dalam basis data vuforia yang telah disediakan unity.

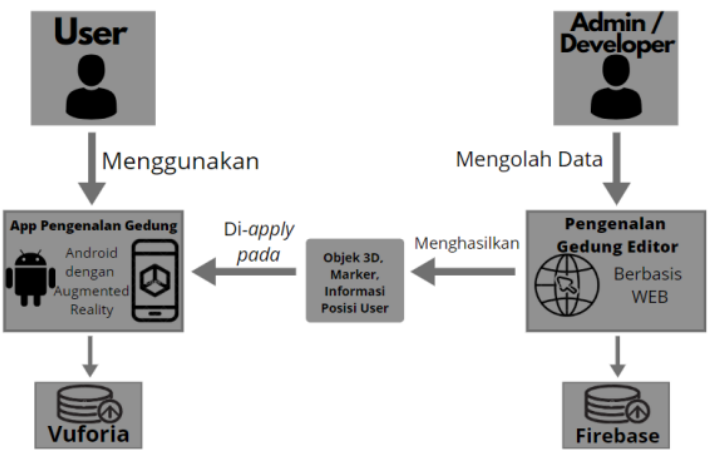

Gambar 5. Arsitektur Aplikasi

Untuk admin, aplikasi yang digunakan untuk mengelola informasi gedung adalah aplikasi web yang diintegrasikan dengan aplikasi mobile. Informasi mengenai informasi dan objek 3D akan disimpan dengan basis data firebase dan dapat diconsume oleh aplikasi mobile tersebut.

\subsubsection{Analisis Proses Pembacaan Marker}

Marker yang digunakan harus cenderung memiliki warna kontras untuk mendapatkan rating terbaik. Hal-hal yang mempengaruhi kinerja marker adalah :

\section{A. Target Star Rating}

Peringkat bintang target adalah dari skala 1-5. Meskipun target dengan peringkat rendah (Bintang 0,1 atau 2) biasanya masih dapat dikenali tetapi bintang 3,4 atau 5 akan menghasilkan hasil terbaik.

\section{B. Mode Fokus Kamera}

Marker akan dikenali lebih baik lagi dengan fokus kamera yang bagus. Gambar yang buram dan tidak menunjukkan detail target akan lama untuk dikenali.

\section{Kondisi Cahaya}

Cahaya harus sudah dipastikan dalam keadaan baik sehingga detail dari scene dan target dapat dilihat dan terdeteksi oleh kamera.

\section{Ukuran Target/Marker}

Marker yang telah dicetak dalam bentuk gambar sebaiknya mempunyai lebar 5 inci atau $12 \mathrm{~cm}$.

\section{E. Sudut Pandang}

Sudut pandang kamera adalah salah satu pengaruh kemudahan pembacaan marker. Marker akan lebih sulit dikenali jika marker dilihat dari sudut yang sangat curam. Ketika mendeteksi marker, pastikan kamera menghadap dengan selaras ke arah marker. Hal tersebut akan memberi peluang tinggi untuk marker dapat dikenali dengan cepat.

\subsection{Desain}

Desain sistem yang dilakukan adalah pembuatan marker dan pembangunan objek 3D. Pada tahap ini dilakukan pemodelan objek 3D yang merupakan perwakilan bentuk gedung yang asli pada lingkungan kampus. Pemodelan dapat dilihat pada Gambar 6.

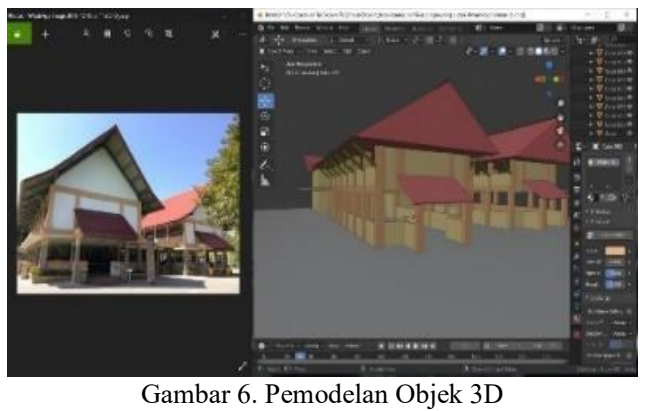

Perancangan struktur menu menampilkan berbagai menu yang tersedia pada aplikasi. Semua menu yang ada pada aplikasi digambarkan dengan bentuk hirarki. Tiap-tiap menu terhubung dengan satu garis yang menyatakan adanya hubungan dari menu satu ke menu lainnya. Perancangan struktur menu dapat dilihat pada Gambar 7.

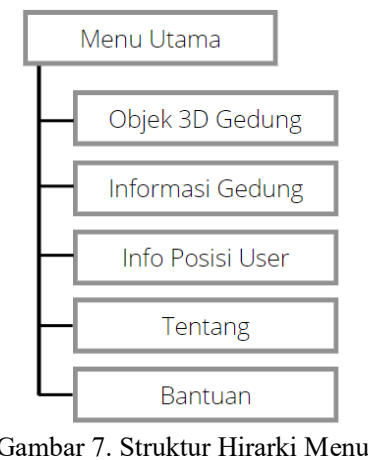

Selain pilihan untuk menu awal atau utama, disediakan menu lain yang dapat dipilih oleh pengguna. Scan Marker adalah menu selanjutnya yang dapat di-klik pengguna untuk memulai proses tracking marker. Di dalam menu ini terdapat algoritma pendeteksian marker langsung pada marker sehingga ketika pengguna mengarahkan kamera ke marker, dan ketika marker berhasil 
dikenali, Objek 3D akan muncul. Selanjutnya, pengguna dapat memilih menu lanjutan yaitu informasi gedung dan posisi user.

\subsubsection{Perancangan Marker Gedung}

Menurut penelitian, penggunaan marker-based $A R$, aplikasi pengenalan gedung membutuhkan sebuah marker khusus untuk setiap gedung. Marker yang digunakan adalah sebuah tanda khusus yang hanya dimiliki oleh gedung tersebut. Tetapi dari semua gedung, tidak semua gedung memiliki tanda khusus sehingga dirancang sebuah marker untuk mewakili gedung tersebut. Contoh marker dapat dilihat pada Tabel 1.

Tabel 1. Contoh Marker dan Keterangan

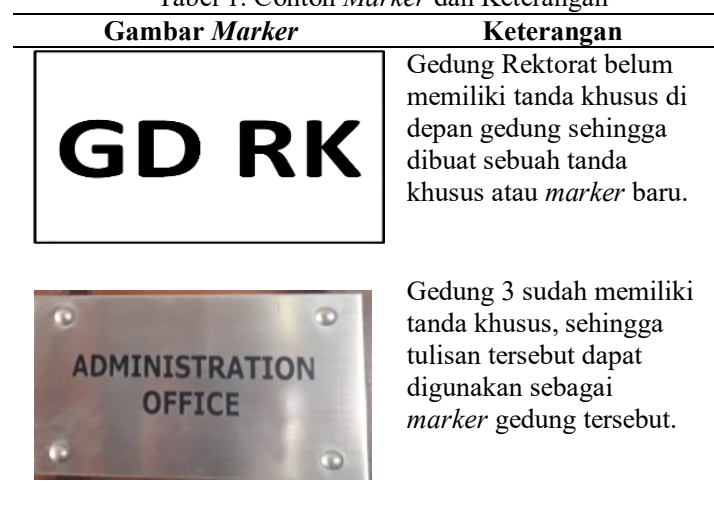

Marker yang sudah dirancang, akan disimpan ke dalam database Vuforia dengan rincian:

1. Target Name, adalah nama dari objek marker.

2. Type, merupakan tipe dari objek marker.

3. Rating, merupakan nilai dari kesensitifan objek marker.

4. Status, adalah status marker yang aktif.

\subsubsection{Perancangan Objek 3D}

Objek virtual yang digunakan pada aplikasi ini adalah sebuah objek 3D dari semua gedung yang ada di IT Del. Contoh Objek 3D dapat dilihat pada Gambar 8 dan Gambar 9.

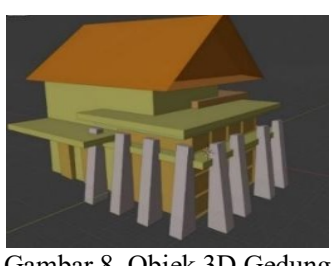

Gambar 8. Objek 3D Gedung Rektorat

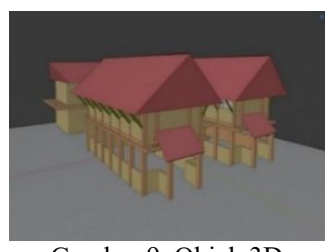

Gambar 9. Objek 3D Kantin Baru

\subsection{Implementasi}

Pada bagian ini akan dijelaskan mengenai aktivitas yang dilakukan dalam proses implementasi beserta penjelasan yang telah dilakukan dalam pembangunan aplikasi.

\subsubsection{Implementasi Tampilan Aplikasi}

Pada bagian ini ditampilkan aplikasi AR yang sudah dibangun. Pada Gambar 10 - 13, diberikan gambaran saat aplikasi android melakukan scan marker dahulu. Marker akan diidentifikasi oleh kamera dan melakukan pencarian dengan marker yang serupa di dalam database. Jika marker ditemukan, kemudian aplikasi akan mengeluarkan dan menampilkan objek 3D gedung. Terdapat dua button yang dapat diklik setelah marker dikenali yaitu informasi dan posisi user.
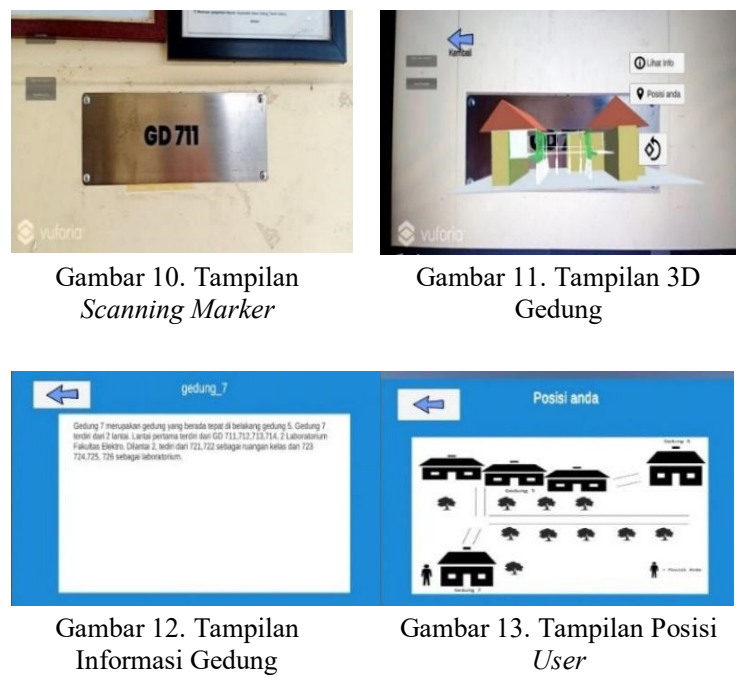

\subsection{Pengujian}

Pengujian yang dilakukan dalam lingkungan pengembang adalah untuk memastikan bahwa aplikasi yang telah diimplementasikan telah berjalan dengan baik dan bebas dari error. Pengujian yang dilakukan adalah black-box dan usability testing. Pengujian usability dengan metode SUS yang dilakukan terhadap 20 responden menghasilkan kesimpulan bahwa kepuasan pengguna mendapat angka 83,4 \% yang artinya aplikasi pengenalan gedung kampus ini berjalan baik sesuai dengan kebutuhan pengguna. Hasil usability testing dapat dilihat pada Tabel 2.

\begin{tabular}{llc}
\multicolumn{3}{c}{ Tabel 2. Usability Testing } \\
\hline $\begin{array}{l}\text { N } \\
\text { o }\end{array}$ & Pertanyaan & Skor \\
\hline 1. & $\begin{array}{l}\text { Tulisan yang ada pada sistem dapat dibaca } \\
\text { dengan jelas }\end{array}$ & 86 \\
2. & $\begin{array}{l}\text { Bahasa yang digunakan pada sistem mudah } \\
\text { untuk dimengerti }\end{array}$ & 87 \\
3. & Form yang disajikan mudah dipahami & 83 \\
4. & Menu-menu pada sistem mudah dipahami & 84 \\
5. & Tombol-tombol pada sistem mudah dipahami & 79 \\
6. & $\begin{array}{l}\text { Sistem mudah untuk dipelajari cara } \\
\text { penggunaannya }\end{array}$ & 83 \\
7. & $\begin{array}{l}\text { Muncul pesan yang jelas ketika terjadi } \\
\text { kesalahan }\end{array}$ & 81 \\
8. & $\begin{array}{l}\text { Sistem dapat menjalankan perintah yang } \\
\text { diinginkan dengan cepat }\end{array}$ & 82 \\
\hline
\end{tabular}




\begin{tabular}{lll}
\hline 9. & $\begin{array}{l}\text { Sistem dapat menampilkan informasi gedung } \\
\text { sesuai dengan marker yang diarahkan dari } \\
\text { smartphone dengan cepat }\end{array}$ & 82 \\
10 & $\begin{array}{l}\text { Menu yang ditampilkan mudah untuk diingat } \\
.\end{array}$ & 86 \\
11 & Cara penggunaan sistem mudah diingat & 89 \\
\hline & & 922 \\
\hline & Jumlah skor & 83,4 \\
\hline
\end{tabular}

\section{KESIMPULAN}

Berdasarkan pembangunan aplikasi yang telah dilakukan, maka diambil kesimpulan bahwa aplikasi android pengenalan gedung dengan teknologi Augmented reality berbasis marker telah sesuai dengan analisis dan perancangan.

Berdasarkan pengujian fungsional, semua fitur yang ada pada aplikasi dapat berjalan dengan baik sesuai dengan kebutuhan. Menurut salah seorang mahasiswi baru yang diwawancarai aplikasi ini berhasil menjadi wadah informasi kampus yang sangat membantu mahasiswa - mahasiswi baru untuk mengenali kampus tanpa berada di sekeliling kampus sampai waktu yang ditentukan.

\section{UCAPAN TERIMA KASIH}

Terima kasih kepada LPPM (Lembaga Penelitian dan Pengabdian Masyarakat) Institut Teknologi Del yang memberikan dana penyelenggaraan dalam melaksanakan penelitian ini.

\section{DAFTAR PUSTAKA}

AN, JIAHUI., CHENG, XINRONG., WANG, QING., \& CHEN., HONG. 2019. Implementation of attractions roaming system based on Unity 3D. Journal of Physics: Conference Series.

AZUMA, R. 1997. A Survey of Augmented reality. Presence: Teleoperators and Virtual Environments, 6, 355-385.

CHRISTOPER. 2012. Markerless Augmented reality for Panoramic Sequences. School of Information Technology and Engineering Faculty of Engineering University of Ottawa Canada.

DIMARZIO, J. F. 2017. Beginning Android Programming with Android Studio. Indianapolis, Indiana: John Wiley \& Sons.

DOVRAMADJIEV, TIHOMIR. 2018. Blender Tutorial Animation Basics - Transforming 3D Geometry ith Shape Keys. Technical University of Varna : Department Industrial Design.

JONATHAN J. HULL. 2007. Paper-Based Augmented reality. International Journal Of Institute of Electrical and Electronics Engineers.

LYU, MICHAEL R. 2012. Digital Interactive Game Interface Table Apps for Ipad. Jurnal
Penelitian. The Chinese University of Hongkong.

PRASETYA, R., HIDAYAT, E. W., SHOFA, R. N. 2018. Pengembangan Aplikasi Panduan Pengenalan Kampus Universitas Siliwangi Berbasis Augmented Reality Pada Perangkat Android. JuTISI.

PUTRA, A.W. 2015. Vuforia - SDK Canggih untuk mewujudkan Aplikasi dan Game dengan Teknologi Augmented Reality, https://teknoijurnal.com/vuforia (di akses 28 Januari).

SUDJANA, NANA. 2011. Penilaian Hasil Proses Belajar Mengajar. Bandung: PT Remaja Rosdakarya.

QUALCOMM. 2012.

WIRADARMA, I. G. G. R., DARMAWIGUNA, I. G. M., dan SUNARYA, I. M. G. 2017. Pengembangan Aplikasi Markerless Augmented Reality Balinese Story 'I Gede Basur'. J. Nas. Pendidik. Tek. Inform. JANAPATI 
Halaman ini sengaja dikosongkan 